\title{
Fibroblast contractility and actin organization are stimulated by microtubule
}

\section{inhibitors}

\author{
BARBARA A. DANOWSKI
}

Department of Biology, Coker Hall CB no. 3280, University of North Carolina, Chapel Hill, North Carolina 27599-3280, USA

\section{Summary}

Despite considerable evidence that cytoplasmic microtubules play some role in guiding or controlling the locomotion of tissue cells, the nature of this control is not understood. In particular, little is known about the role of microtubules in the exertion of propulsive 'traction' forces, or about microtubule effects on the organization of the cytoplasmic actin stress fibers. In this study, the silicone rubber substratum technique was used in combination with fluorescence microscopy in order to observe the effects of microtubule-depolymerizing drugs on the contractile strength and organization of cytoplasmic actin networks.

Perfusion with a variety of microtubule poisons (either colcemid, nocodazole or vinblastine) was found to cause a rapid and substantial strengthening of fibroblast contractility. This was demonstrated in two established fibroblast cell lines, as well as in primary cultures of rat gingival fibroblasts and embryonic chick heart fibroblasts. Treatment with the drug taxol, which promotes micro-

tubule assembly, was found to prevent the strengthening effects of the microtubule inhibitors. It was also found that the disruption of actin stress fibers by the phorbol ester tumor promoter, TPA, is reversed by microtubule poisons: stress fibers reform within $30 \mathrm{~min}$ of the addition of the microtubule drugs, despite the continued presence and activity of the TPA.

Several possible mechanisms are considered, including the idea that microtubule assembly normally exerts a pushing force, which counterbalances part of the contractile force exerted by the actin stress fibers. However, the mechanism that seems best to account for the observations is that microtubules modulate, in an inhibitory fashion, the contractility and the state of organization of cytoplasmic actin.

Key words: microtubules, cell contractility, actin organization, phorbol ester tumor promoters, silicone rubber substratum, colcemid, nocodazole, vinblastıne.

\section{Introduction}

The crawling locomotion of fibroblasts and other tissue cells results from their exertion of contractile 'traction' forces on objects and materials to which they adhere (Harris et al. 1980; Harris, 1986). Considerable evidence also exists to show that these traction forces also serve other important morphogenetic functions, in particular the reorganization and alignment of collagen to form relatively large-scale anatomical structures (Harris et al. 1981; Stopak \& Harris, 1982). These cellular traction forces are known to be generated by networks of cytoplasmic actin and myosin (Pollard et al. 1976; Trinkaus, 1984; Bershadsky \& Vasiliev, 1988), but much remains to be learned about the mechanisms that control the organization and contractile state of these acto-myosin networks.

Several lines of evidence have implicated microtubules as playing some controlling role in the motility of tissue cells: microtubule-depolymerizing drugs have been shown to cause a loss in directionality or polarity of locomoting cells (Vasiliev et al. 1970; Gail \& Boone, 1971 ), to cause the retraction of growing nerve growth cones (Solomon \& Magendantz, 1981; Joshi et al. 1985), to cause shortening of embryonic chick cells suspended in collagen gels (Tomasek \& Hay, 1984), to promote lectininduced capping in lymphocytes and $3 \mathrm{~T} 3$ cells (Edelman et al. 1973; Poste et al. 1975) and to reduce the inhibition of this capping by actin-poisoning drugs (Poste et al. 1975). More recently, Dugina et al. (1987) have observed that colcemid produces a reversal of the morphological changes induced by tumor promoters.

This last finding is especially interesting, since the tumor-promoting phorbol esters are known to have a dramatic effect on the organization of cytoplasmic actin (Rifkin et al. 1979; Schliwa et al. 1984) and cell contractility (Danowski \& Harris, 1988; Lyass et al. 1988). Therefore, the present study was undertaken in order to determine what role microtubules play in the exertion of traction forces. The silicone rubber substratum tech- 
nique (Harris et al. 1980) was used in conjunction with time-lapse cinemicrography and fluorescence microscopy, in order to study the responses of tissue culture fibroblasts to treatment with several different microtubule inhibitors. Changes in cell contractility were also assessed in the combined presence of microtubule poisons and agents known to disrupt actin stress fibers, including the phorbol ester tumor promoter, TPA (12-Otetradecanoylphorbol-13-acetate), forskolin and isobutylmethylxanthine (Rifkin et al. 1979; Schliwa et al. 1984; Lamb et al. 1988). The results have been surprising and seem to indicate that one of the normal functions of microtubules is the exertion of some form of inhibitory control on the cells' contractile strength and the state of organization of cytoplasmic actin microfilaments.

\section{Materlals and methods}

\section{Cell culture}

$\mathrm{C} 3 \mathrm{H} / 10 \mathrm{~T} 1 / 2$ mouse embryo fibroblasts (kindly provided by Dr K. Jacobson (University of North Carolina, Chapel Hill, NC) were cultured in Eagle's MEM with Hanks' salts, supplemented with $10 \%$ fetal calf serum, 100 units $^{-1}$ penicillin, $100 \mu \mathrm{g} \mathrm{ml}^{-1}$ streptomycin, and $7.5 \mathrm{~mm}-$ Hepes. Cells were removed from tissue culture flasks by a brief treatment with trypsin-EDTA solution (Gibco, Grand Island, NY), and plated onto either glass coverslips or silicone rubber substrata. Cells were used for experimentation 1-5 days after plating.

\section{Silicone rubber substrata}

Silicone rubber substrata were made as described by Harris $e t$ al. (1980). Briefly, thin layers of 30000 centipoise (1 poise$=10^{-1} \mathrm{Pas}$ ) silicone fluid were spread onto glass coverslips, flamed for approximately $1 \mathrm{~s}$, and then placed in sterile $35 \mathrm{~mm}$ Petri dishes. Cells were plated directly onto the rubber substrata in a volume of $0.5 \mathrm{ml}$. After the cells had attached, an additional $3.0 \mathrm{ml}$ of medium was carefully added to the dishes.

\section{Drug treatment}

Nocodazole (methyl(5-[2-thienylcarbonyl]-1H-benzimidazol2-YL) carbamate), vinblastine sulfate, colcemid (Demecolcine), and dibutyryl adenosine $3^{\prime}-5^{\prime}$-cyclic monophosphoric acid (dbcAMP) were purchased from Sigma, St Louis, MO, and TPA was obtained from LC Corp., Woburn, MA. Stock solutions of these drugs were dissolved in dimethylsulfoxide (DMSO) (TPA, $100 \mathrm{mg} \mathrm{ml}^{-1}$; nocodazole, $5 \mathrm{mg} \mathrm{ml}^{-1}$; vinblastine, $10 \mathrm{mg} \mathrm{ml}^{-1}$, dbcAMP, $1 \mathrm{M}$ ) or distilled water (colcemid, $1 \mathrm{mg} \mathrm{ml}^{-9}$ ), aliquoted, and stored frozen until use. These drugs were added to cell cultures to give final concentrations of $100 \mathrm{ng} \mathrm{ml}^{-1} \mathrm{TPA}, 5 \mu \mathrm{g} \mathrm{ml}^{-1}$ nocodazole, $10 \mu \mathrm{g} \mathrm{ml}^{-1}$ vinblastine, $1 \mu \mathrm{g} \mathrm{ml}^{-1}$ colcemid, and $1 \mathrm{mM}$-dbcAMP, except where otherwise noted. In every case, the concentration of DMSO in cell cultures never exceeded $0.1 \%$.

Taxol was kindly provided by N. K. Pryer, University of North Carolina, Chapel Hill $(10 \mathrm{~mm}$ stock solution in DMSO, stored at $0^{\circ} \mathrm{C}$ ). Cells were treated with $10 \mu \mathrm{m}$-taxol for $12-16 \mathrm{~h}$ before use. Forskolin and 3-isobutyl-1-methylxanthine (IBMX) were provided by Dr Wendell Combest, University of North Carolina, Chapel Hill. Forskolin $(20 \mathrm{~mm}$ stock solution in DMSO, stored at $0^{\circ} \mathrm{C}$ ) was used at concentrations ranging from $10 \mu \mathrm{M}$ to $60 \mu \mathrm{M}$; IBMX ( $1 \mathrm{~m}$ stock solution in DMSO) was used at a concentration of $1 \mathrm{~mm}$.

\section{Time-lapse filming}

Cell behavior on the silicone rubber substrata prior to and following the addition of the various drugs was recorded on Kodak Plus-X Reversal film, using a Sage time-lapse apparatus attached to an Olympus inverted microscope. Frames were taken at 1 -min intervals. Temperature was maintained at $37^{\circ} \mathrm{C}$ by a Sage air-curtain incubator.

\section{Immunofluorescence}

Single-labelıng of $\mathrm{f}$-actin: cells grown on glass coverslips were fixed in $3.7 \%$ formaldehyde in phosphate-buffered saline (PBS) for $10 \mathrm{~min}$ at room temperature, washed, and then incubated at $37^{\circ} \mathrm{C}$ for $45 \mathrm{~min}$ with rhodamine-conjugated phalloidin, a mushroom toxin that binds specifically to $f$-actin (Molecular Probes, Eugene, OR).

Double-labelling of actin and tubulin: cells grown on glass coverslips were fixed at room temperature for $10 \mathrm{~min}$ in a mixture of $2 \%$ formaldehyde and $0.1 \%$ glutaraldehyde in PHEM buffer ( $60 \mathrm{~mm}$-Pipes, $25 \mathrm{~mm}$-Hepes, 5-10 mM-EGTA and $1 \mathrm{~mm}-\mathrm{MgSO}_{4} \cdot 7 \mathrm{H}_{2} \mathrm{O}$ ), and extracted in $0.5 \%$ Triton X-100 in PHEM buffer for $2 \mathrm{~min}$. Coverslips were incubated for $1 \mathrm{~h}$ at $37^{\circ} \mathrm{C}$ with a monoclonal antibody that recognized beta-tubulin (generously provided by Dr E. D. Salmon, University of North Carolina, Chapel Hill, NC). This was followed by a 1-h incubation with a mixture of a rhodamine-conjugated sheep anti-mouse antibody (Cappel, West Chester, PA) plus nitrobenzooxadiazole-conjugated phallacidin (NBD-phallacidin).

The coverslips were mounted onto microscope slides in either gelvatol or MOWIOL (Calbiochem, La Jolla, CA), and examined using a Zeiss $63 \times, 1.4$ n.a. Planapo objective on a Zeiss IM-35 inverted microscope equipped for epifluorescence.

\section{Results}

\section{Changes in cell contractility produced by colcemid,} vinblastine and nocodazole

Using silicone rubber culture substrata, fibroblast contractility was monitored by time-lapse photograpy following the addition of microtubule-poisoning drugs to the culture medium. Colcemid, nocodazole and vinblastine were each added to cultures at a range of different concentrations. The resulting time-lapse films show that all three of these drugs cause fibroblasts to increase the strength of the contractile forces that they exert on the rubber substrata; this strengthening of cell contractility is visible as a marked increase in the size and number of wrinkles in the rubber sheet (Fig. 1). These increases became visible within 3-5 min after introduction of the drugs. It is important to note that these increases in substratum wrinkling represent an increase in the net contractile forces acting on the cell-substratum adhesions. But as will be discussed later, this increase in the net force exerted could result either from an actual strengthening of the contractility of the actin, or from a weakening of whatever internal pushing forces act to counterbalance the contractility of cytoplasmic actin.

This stimulation of increased contractile strength by microtubule-depolymerizing drugs was observed in all of the types of fibroblasts studied. These included primary cultures of chick heart and rat gingiva, and cells of the established lines IMR-33 (gerbil fibroma) and $\mathrm{C} 3 \mathrm{H} /$ $10 \mathrm{~T} 1 / 2$ (mouse embryo fibroblasts). Although the responses of all of these fibroblasts were substantially the same, the following descriptions refer specifically to the cell line $\mathrm{C} 3 \mathrm{H} / 10 \mathrm{~T} 1 / 2$, unless otherwise noted. 
As a means of quantifying the relative increase in contractility caused by microtubule poisons, measurements were made (from time-lanse films) of the total
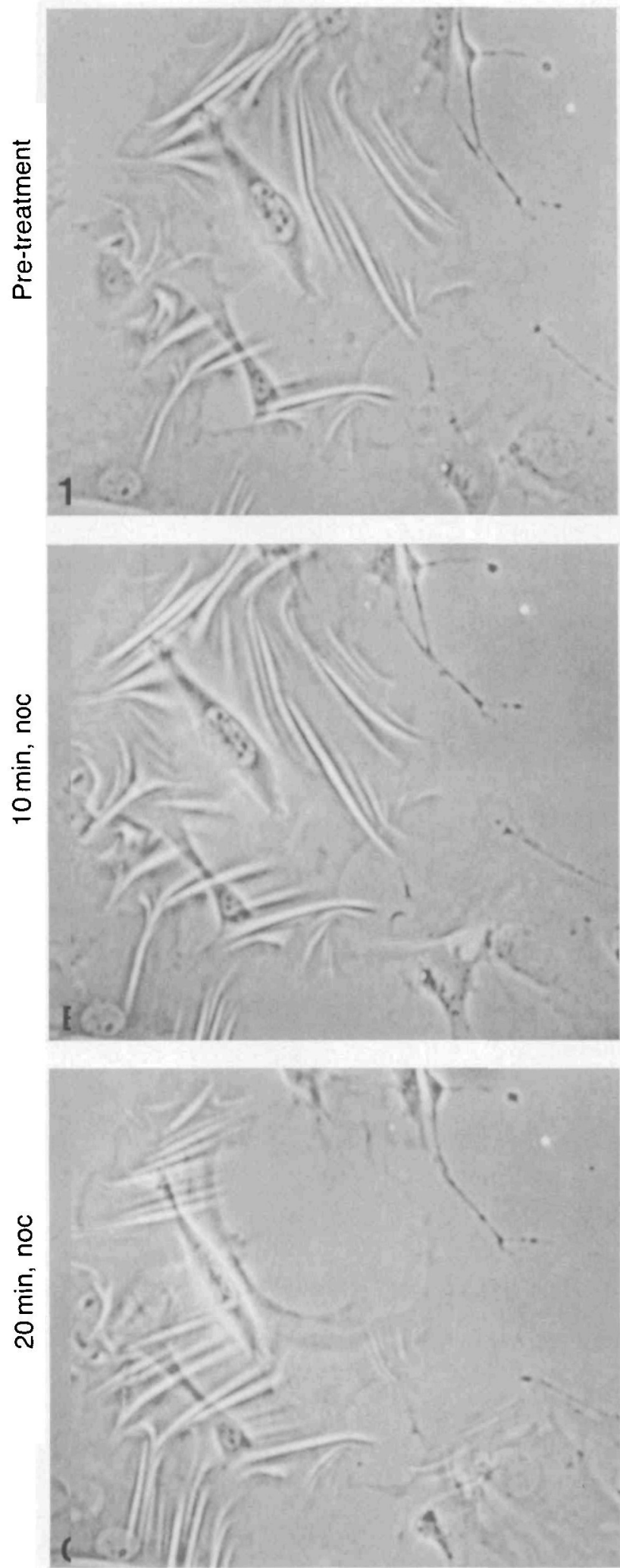

summed lengths of the wrinkles produced in the silicone rubber substrata at successive stages of drug treatment. The larger number and length of substratum wrinkles are

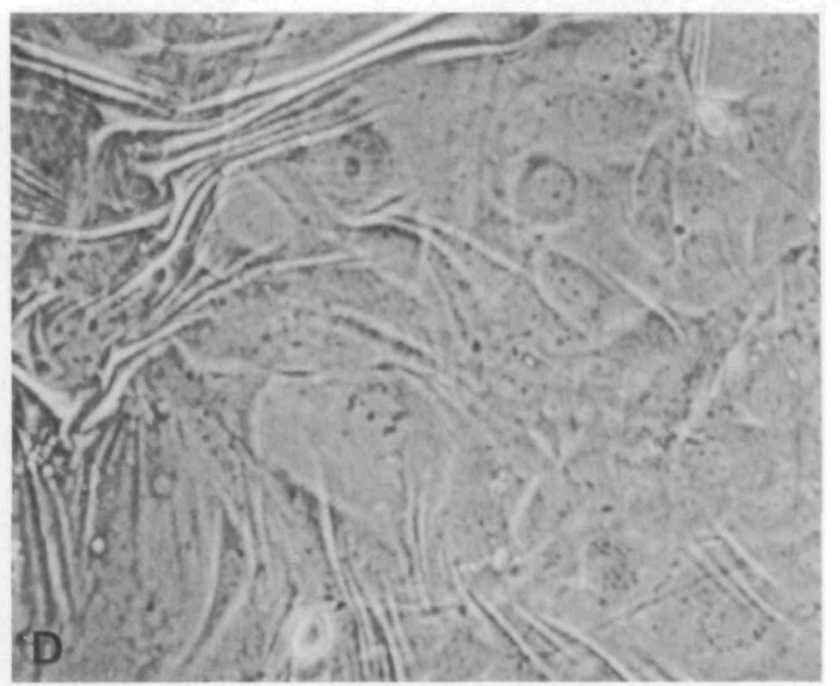

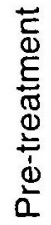

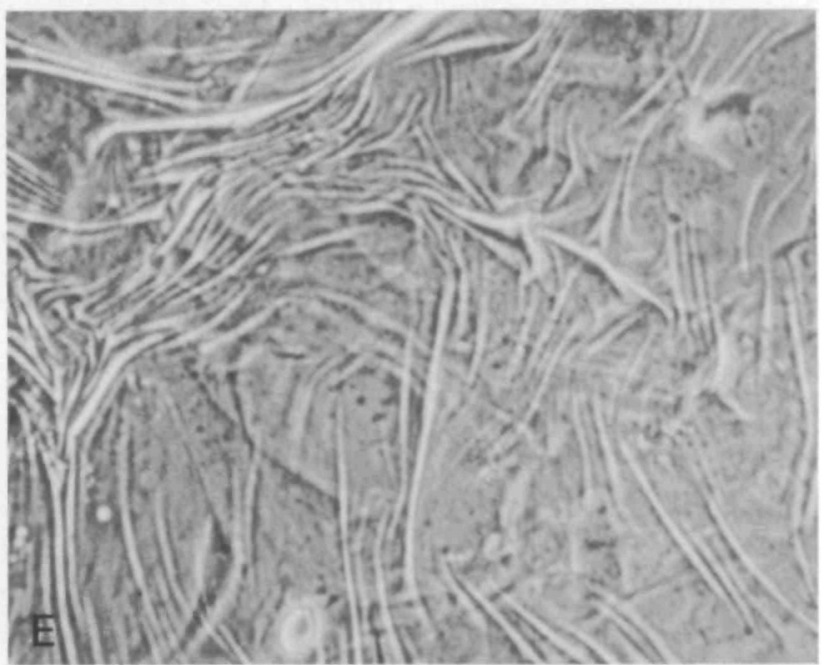

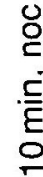

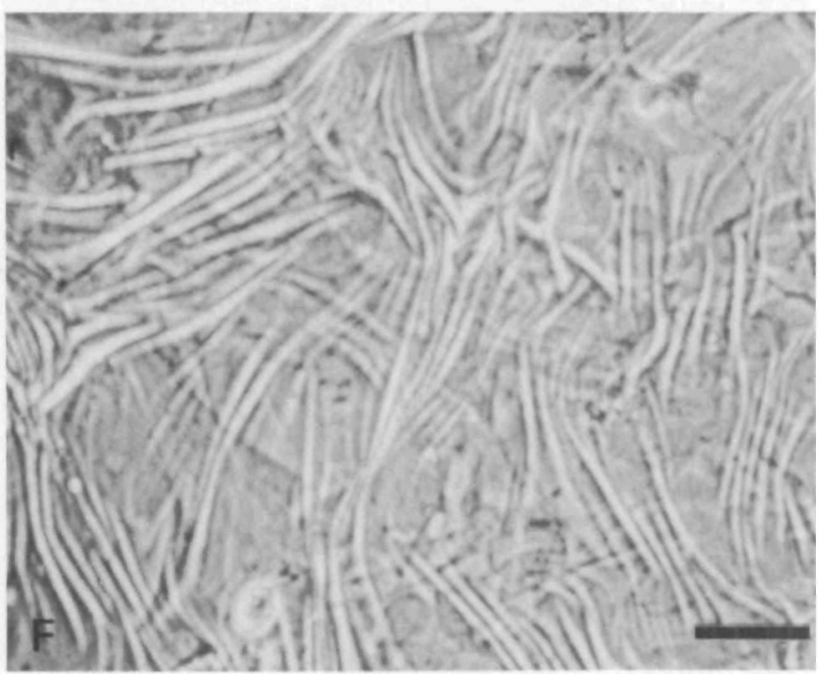

을

Fig. 1. Rapid increase in the contractile strength of $\mathrm{C} 3 \mathrm{H} / 10 \mathrm{~T} 1 / 2$ cells following exposure to $5 \mu \mathrm{g} \mathrm{ml} \mathrm{l}^{-1}$ nocodazole. $\mathrm{A}, \mathrm{B}, \mathrm{C}$. Individual cells; D, E, F, confluent cell sheets. A, D. 1 min before drug treatment; B, E, after 10 min in nocodazole (noc); C, $\mathrm{F}$, after $20 \mathrm{~min}$ in nocodazole. Bar, $50 \mu \mathrm{m}$. 

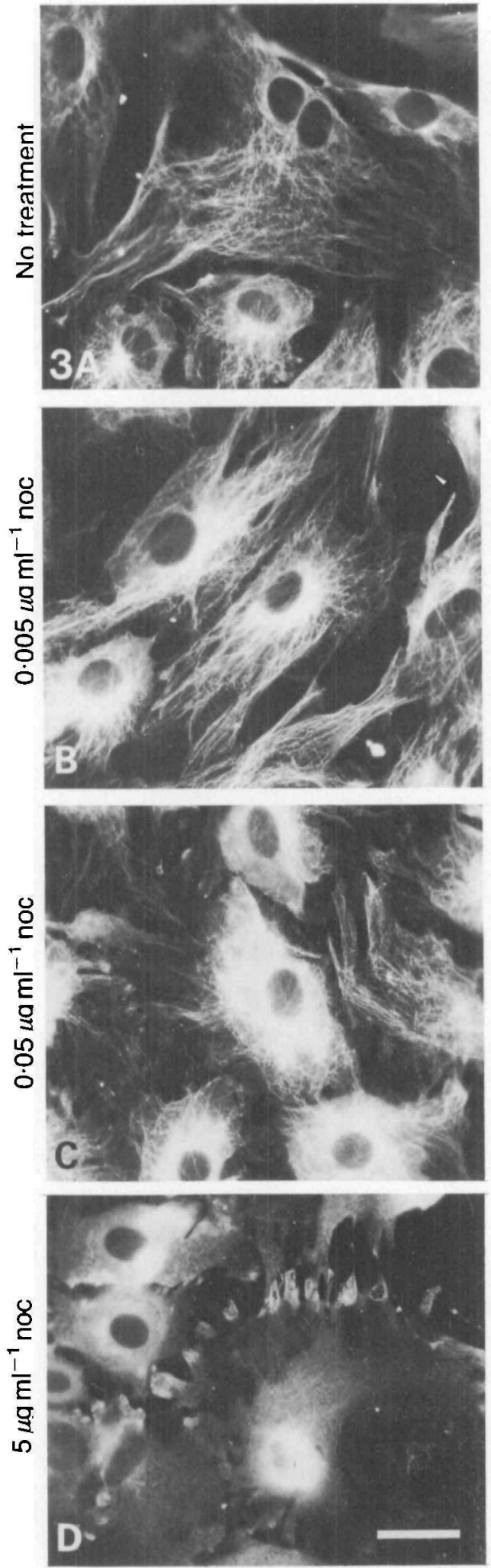

Fig. 3. Demonstration that substantial numbers of microtubules remain in fibroblasts treated with concentrations of microtubule poisons sufficient to induce increased contractility. $\mathrm{C} 3 \mathrm{H} / 10 \mathrm{~T} 1 / 2$ cells were treated with varying concentrations of nocodazole for $30 \mathrm{~min}$, and then fixed and fluorescently stained with a monoclonal antibody to tubulin. A. Control cells; B, $0.005 \mu \mathrm{g} \mathrm{ml}^{-1}$ nocodazole; C, $0.05 \mu \mathrm{g} \mathrm{ml}^{-1}$ nocodazole; $\mathrm{D}, 5 \mu \mathrm{g} \mathrm{ml}^{-1}$ nocodazole. Bar, $30 \mu \mathrm{m}$.
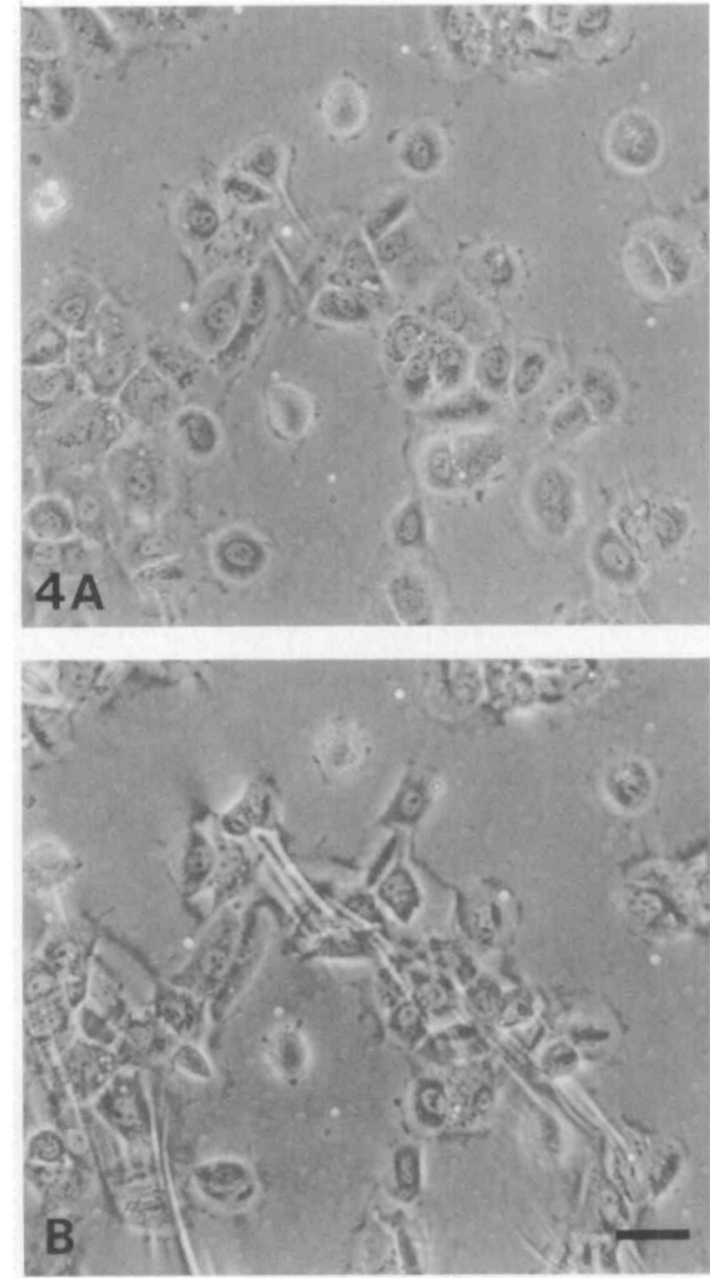

Fig. 4. Removal of taxol-containing medium, and replacement with medium containing nocodazole results in an increase in cell contractility. A. C3H/10T1/2 cells in taxolcontaning medium for $15 \mathrm{~h}$; B, these same cells $70 \mathrm{~min}$ after the simultaneous removal of taxol and addition of $5 \mu \mathrm{g} \mathrm{ml}^{-1}$ nocodazole. Bar, $50 \mu \mathrm{m}$.

wrinkling; and in four cases, an increase in wrinkling occurred, in three of which the increase involved a retraction of the cells, followed by a gradual respreading. This respreading was often accompanied by a re-wrinkling of the rubber sheet.

The ability of taxol to interfere with the effects of the microtubule poisons was also investigated. Cells were first incubated in taxol for extended periods $(6-15 \mathrm{~h})$ and then perfused with $1 \mu \mathrm{g} \mathrm{ml}^{-1}$ colcemid or, in other experiments, with $5 \mu \mathrm{g} \mathrm{ml}^{-1}$ nocodazole (in the continued presence of taxol). These cells underwent no apparent change in contractility in response to the colcemid or the nocodazole. But, when the medium containing the taxol plus nocodazole was washed out and replaced by medium containing nocodazole alone, a marked increase in cell contractility was seen within 30 min (Fig. 4). Thus, the microtubule-stabilizing drug taxol, by itself, causes neither a decrease nor an increase in cell contractility, but does block the increase in cell 

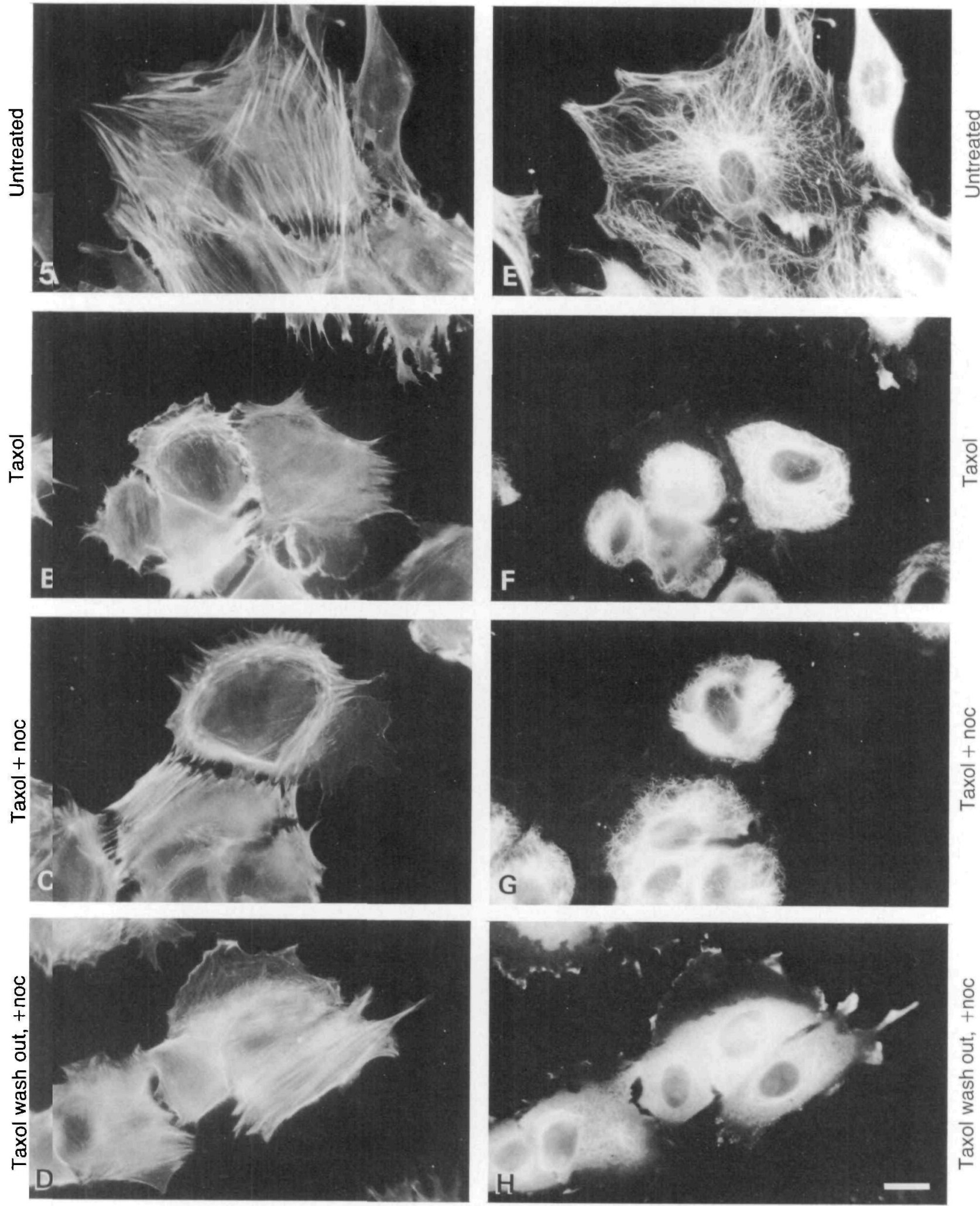

Fig. 5. Effects of taxol and nocodazole on cytoplasmic distributions of f-actin (left column) and tubulin (right column). Notice that stabilization of microtubules with taxol causes these microtubules to be concentrated around the nucleus and absent from the peripheral cytoplasm, into which the actin filaments still extend $(5 \mathrm{~B}, \mathrm{~F})$. This is significant in relation to the increased traction exerted by these cells when the taxol is removed and nocodazole added $(5 \mathrm{D}, \mathrm{H})$, because the short, centrally located microtubules could not have been exerting a pushing force on the periphery. A, E, untreated; B, F, cells incubated in taxol for $16 \mathrm{~h} ; \mathrm{C}, \mathrm{G}$, taxol-treated cells incubated in $5 \mu \mathrm{g} \mathrm{m} \mathrm{l}^{-1}$ nocodazole for $60 \mathrm{~min} ; \mathrm{D}, \mathrm{H}$, cells in nocodazole for $60 \mathrm{~min}$ after the removal of the taxol-containing medium. Bar, $20 \mu \mathrm{m}$. 
contractility that is otherwise caused by microtubuleinhibiting drugs.

Cells were also treated with $10 \mu \mathrm{m}$ taxol for $14-16 \mathrm{~h}$, and then fixed and stained with fluorescent probes for tubulin and f-actin. Such cells contained numerous closely packed microtubules concentrated in the centers of the cells (Fig. 5B,F). These microtubules appeared to be excluded from the thin, peripheral areas of the cytoplasm; this was in contrast to the actin-containing stress fibers, which often spanned the entire length of the cell. When taxol-treated cells were also treated with microtubule poisons prior to fixation, there was no apparent alteration in the appearance or distribution of microtubules (Fig. 5C,G).

\section{Microtubule poisons counteract the dismuption of stress fibers caused by TPA}

We examined the question of whether the increase in cell contractility resulting from treatment with microtubule poisons could be altered by TPA. Two parallel sets of experiments were carried out: cells were exposed to TPA for $30-90 \mathrm{~min}$, and then additionally treated with a microtubule poison (in the continued presence of TPA) or, conversely, cells were treated first with a microtubule poison for $30-90 \mathrm{~min}$, and then exposed to TPA (in the continued presence of the microtubule poison). Timelapse films recorded any resulting changes in cell contractility (Fig. 6), while immunofluorescence microscopy of fixed cells provided information on changes in cytoskeletal organization (Fig. 7).

TPA first, microtubule poison second. Cell cultures treated with TPA alone lost all substratum wrinkles within 8-15 min (Fig. 6A,B). However, when these TPA-treated cells were subsequently exposed to $5 \mu \mathrm{g} \mathrm{ml}^{-1}$ nocodazole, contractility was rapidly restored (Fig. 6C). Substratum wrinkles reappeared within 10 min of the addition of nocodazole, despite the continued presence of the TPA. This effect was reversible: the removal of the TPA- and nocodazole-containing medium and replacement by ordinary tissue culture medium resulted in the loss of substratum wrinkles within $30 \mathrm{~min}$, and the restoration of a cell morphology characteristic of TPA-treated cells (Fig. 6D). This latter result corresponds to the long-lasting effects of TPA, which usually persist for $6-8 \mathrm{~h}$ after the removal of the substance from the medium.

The restoration of cell contractility in TPA-treated cells caused by microtubule poisons was accompanied by changes in cytoskeletal organization, as seen by immunofluorescence microscopy. It has been shown (Schliwa $e t$ al. 1984; Danowski \& Harris, 1988) that TPA treatment greatly reduces the number of actin-containing stress fibers (Fig. 7D). However, exposure of TPA-treated cells to depolymerizing doses of microtubule poisons for $30-60$ min prior to fixation results in the reformation of stress fibers (Fig. $7 \mathrm{~F}, \mathrm{H}, \mathrm{J}$ ). Removal of the medium containing TPA and microtubule poison by extensive washing, and replacement with fresh medium, results once again in the disruption of these stress fibers (Fig. 7L).

Nocodazole first, TPA second. As described above,
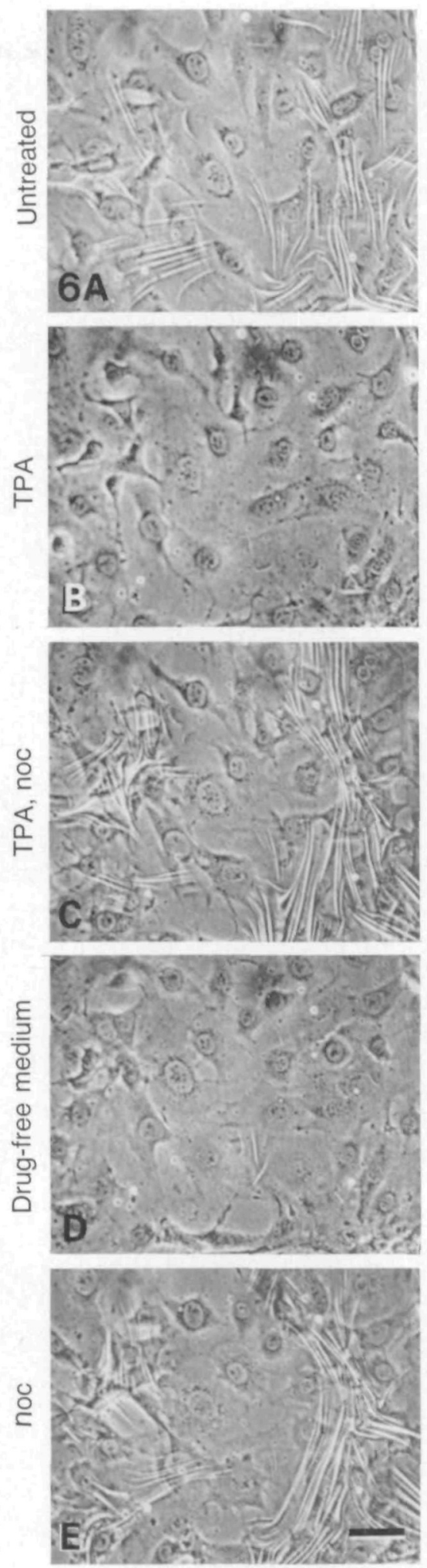

Fig. 6. Nocodazole reverses the effects of TPA on cell contractility and morphology. Successive frames taken from a time-lapse film. A. Untreated $\mathrm{C} 3 \mathrm{H} / 10 \mathrm{~T} 1 / 2$ cells; B, $30 \mathrm{~min}$ in TPA; C, $30 \mathrm{~min}$ after the addition of nocodazole (in the continued presence of TPA); D, 30 min after removal of the drug-containing medium, and replacement with drug-free medium; E, $30 \mathrm{~min}$ after nocodazole added to the drug-free medium. Bar, $60 \mu \mathrm{m}$. 
treatment with nocodazole caused a rapid increase in contractility. When nocodazole-treated cells were then exposed to TPA, the response to TPA was greatly diminished, compared with cells treated with TPA alone. Some weakening of cell contractility did occur in some cells, but only rarely did all substratum wrinkles disappear. Furthermore, those cells that showed a loss in contractility usually regained some of their contractile strength within $30 \mathrm{~min}$. When cells were simultaneously exposed to both nocodazole and TPA, similar results were obtained. Immunofluorescence microscopy showed that prior treatment with either vinblastine or nocodazole prevented the actin rearrangements normally caused by TPA treatment. Whereas TPA-treated cells are lacking in
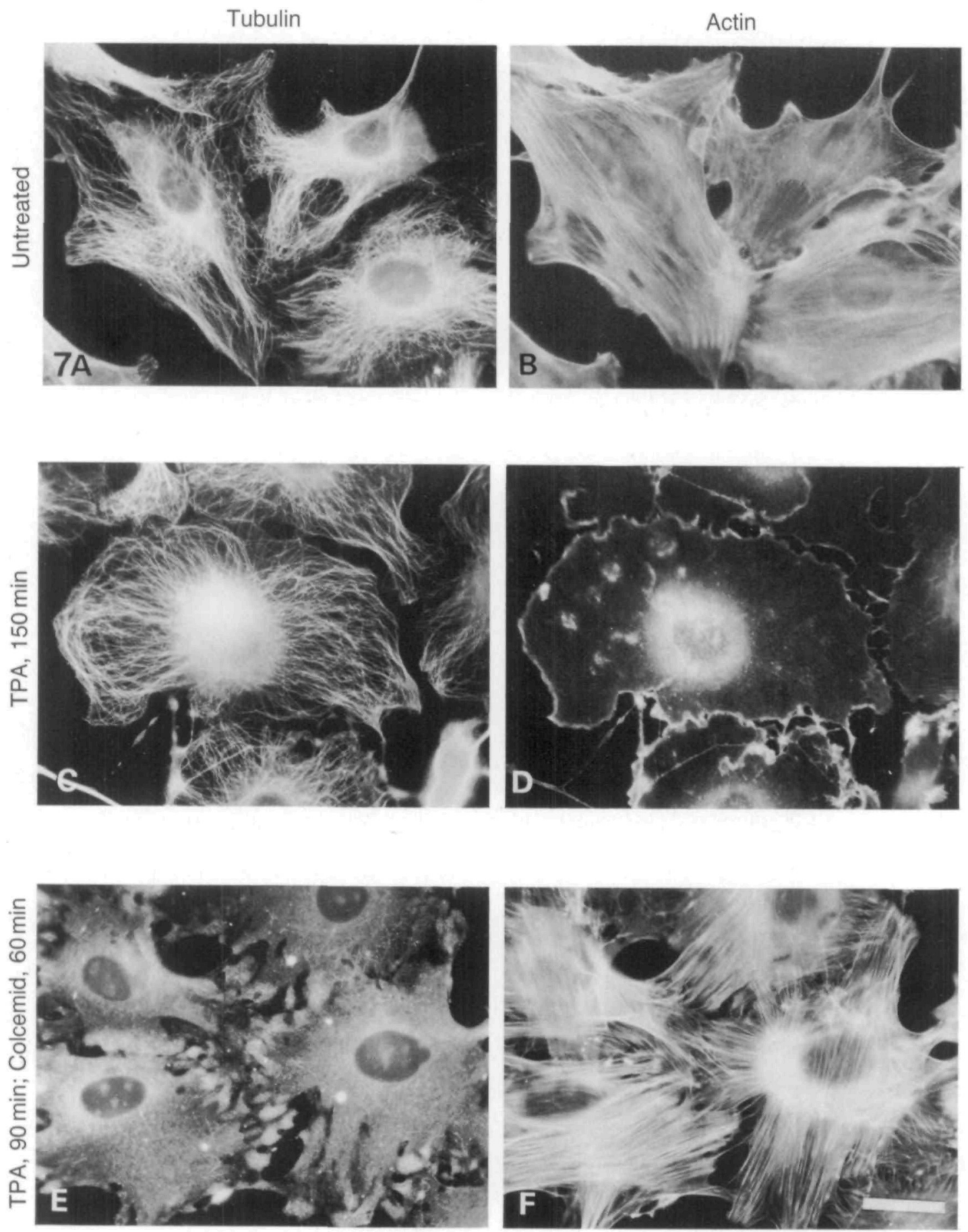

Fig. 7. Microtubule poisons reverse the disruptive effect of TPA on actin-containing stress fibers. Double-labeled immunofluorescence micrograph showing tubulin.(left column) and actin (right column) distribution in C3H/10T1/2 cells. A, B. Untreated cells; C, D, cells treated with TPA for $150 \mathrm{~min}$; E, F, cells incubated in TPA-containing medium for 90 min, and then additionally treated with $1 \mu \mathrm{g} \mathrm{ml}^{-1}$ colcemid for $60 \mathrm{~min}$ before fixation. 
stress fibers, nocodazole-treated cells that had been exposed to TPA for $60 \mathrm{~min}$ prior to fixation contain numerous stress fibers.

A similar set of experiments was performed, except that forskolin or combinations of dbcAMP and isobutylmethylxanthine (IBMX) were used to disrupt the actincontaining stress fibers. These agents are known to elevate intracellular cyclic AMP levels, and stimulate the cyclic AMP-dependent protein kinase (Seamon et al.
1981). Treatment with either 20-60 mM-forskolin or $1 \mathrm{mM}$-dbcAMP plus $1 \mathrm{mM}$-IBMX resulted in both a rapid loss in cell contractility, and a disruption of many stress fiber bundles; subsequent addition of nocodazole (in the continued presence of the cyclic AMP-stimulating drugs) resulted in a strengthening of cell contractility, as well as the reappearance of organized stress fibers (data not shown). Thus, it appears that the weakening of cell contractility and the disruption of stress fibers either by
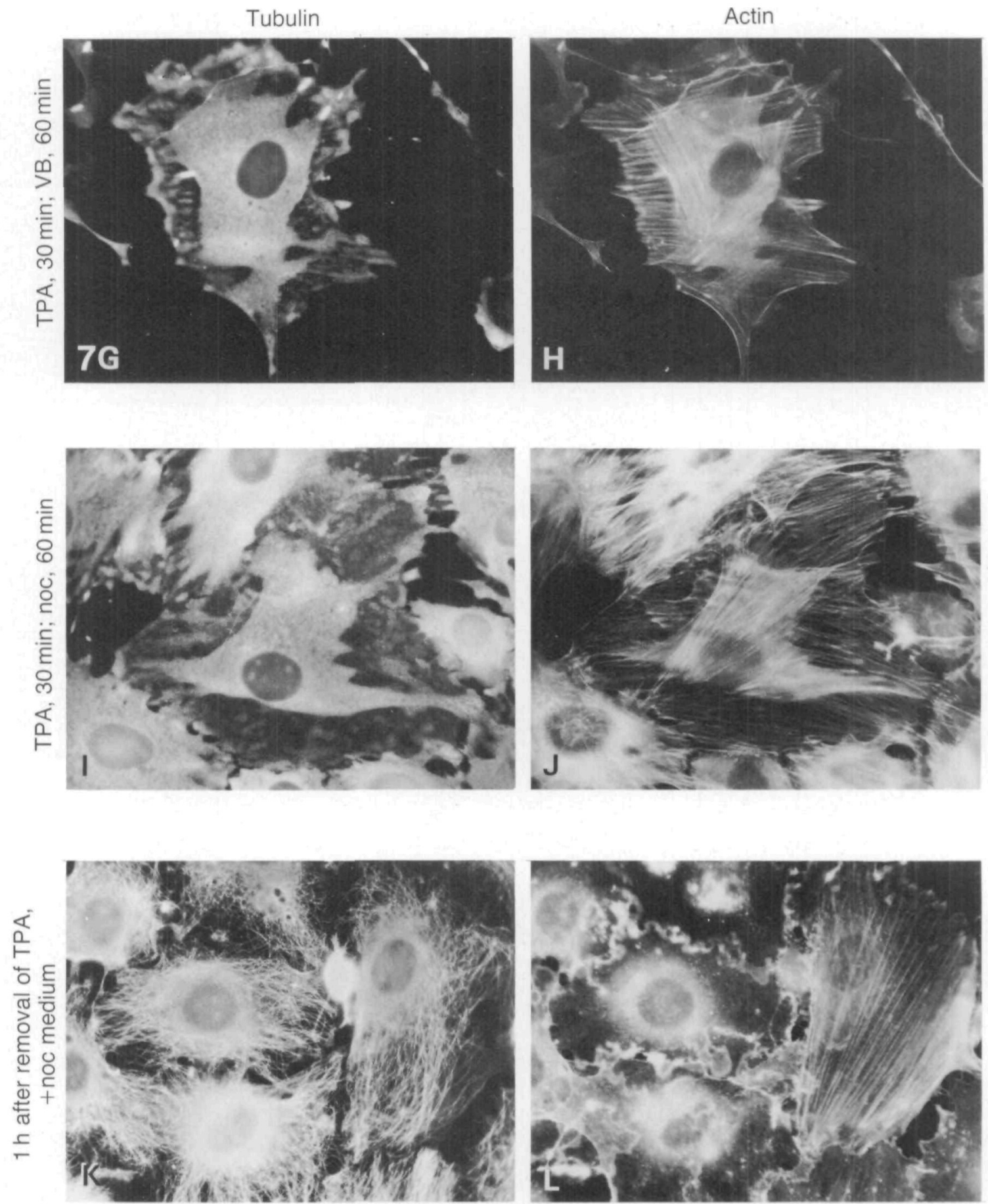

G, H. Cells treated with TPA for $30 \mathrm{~min}$, followed by $10 \mu \mathrm{g} \mathrm{ml}^{-1}$ vinblastine for $60 \mathrm{~min}$; I, J, cells treated with TPA for $30 \mathrm{~min}$, followed by $5 \mu \mathrm{g} \mathrm{m}^{-1}$ nocodazole for $60 \mathrm{~min} ; \mathrm{K}, \mathrm{L}, 60 \mathrm{~min}$ after the removal of the TPA- and nocodazole-containing medium, and replacement with normal, drug-free medium. Bar, $30 \mu \mathrm{m}$. 
the hyperactivation of protein kinase $\mathrm{C}$ (caused by TPA) or by the elevation of intracellular cyclic AMP levels (by either forskolin or by dbcAMP plus IBMX) can be reversed by microtubule poisons.

\section{Discussion}

The results reported here are surprising in several respects. Previous observations of morphological changes caused by microtubule poisons (Vasiliev et al. 1970; Gail \& Boone, 1971) might have led one to expect some gradual reduction in the directionality of fibroblast contractility, but not the rapid increases in contractile strength that actually occur. And despite recent observations that microtubule poisons block the morphological effects of the tumor promoter, TPA (Dugina et al. 1987), it was quite unexpected to find that these microtubule inhibitors also cause a rapid restoration of actin-containing stress fibers, even after these had been disrupted by TPA or by other agents.

Several types of possible explanations for these results have been considered. The first is that the increased contractility could represent some kind of side effect of the microtubule-poisoning drugs, rather than a result of their effects on microtubules. However, the following facts seem to contradict this possibility: (1) the same increases in cell contractility are produced by all three of the microtubule inhibitors investigated (even though vinblastine acts on a different site on the tubulin molecule from nocodazole or colcemid; Dustin, 1984); (2) all three of the drugs produce increased contractility at very low concentrations; and (3) prior stabilization of the microtubules by taxol was found to prevent the microtubule inhibitors from inducing increased contractility.

A second possible explanation for the observed increase in contractility is that it might result from a collapse of the normal cytoplasmic arrays of intermediate filaments, since these filaments have been shown to collapse in fibroblasts whose microtubules have been disrupted by microtubule inhibitors (Starger et al. 1978). However, this redistribution of intermediate filaments occurs $5 \mathbf{h}$ or more after exposure to microtubule-poisoning drugs (De Brabander et al. 1975), whereas the increased contractility observed here occurred within 5 min of treatment with these drugs. So this possible explanation seems inconsistent with the rapid time course of the effect.

A third possible explanation, shown diagrammatically in Fig. 8A, is that cytoplasmic microtubules normally exert a large pushing force, and that this push partially counterbalances the pull of the actin stress fibers. Thus, when the microtubules are disrupted by anti-microtubule drugs, a greater proportion of contractile forces of the stress fibers would be exerted on the substratum, thereby producing the increased distortion. In this type of model, there need not be any actual increase in the contractile forces generated by the cells' actin and myosin. Rather, the predominant effect is a redistribution of the cellular forces. This hypothesis is closely analogous to the 'tensegrity' or 'force counterbalance' models of Heidemann

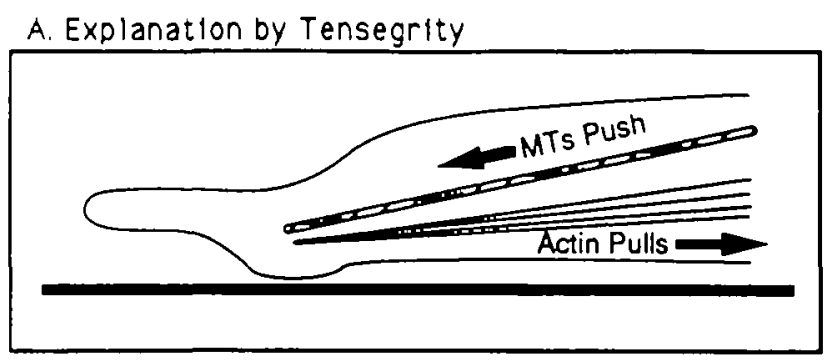

B. Explanation by MT-inhibition of Actin Function

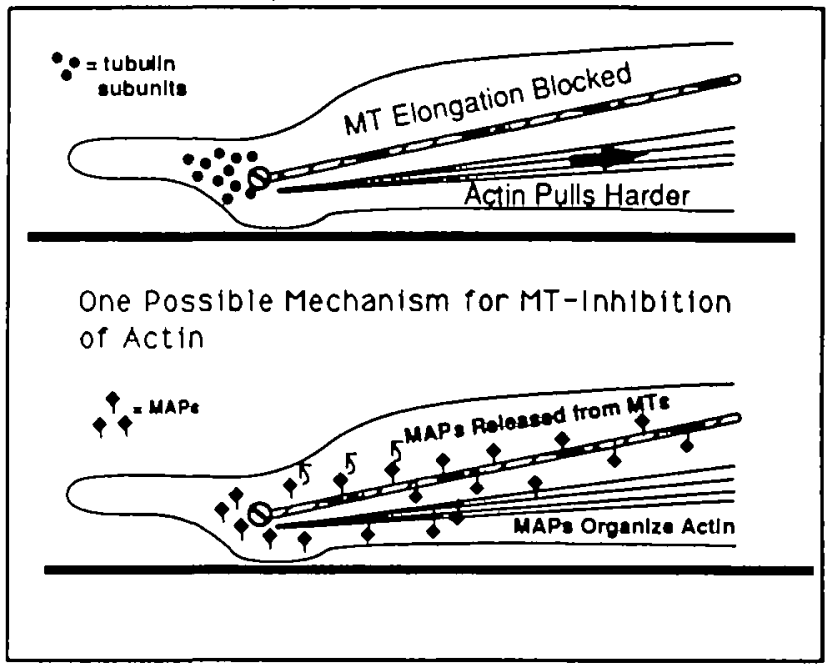

Fig. 8. Some possible explanations for the observed increase in contractility and actin organization as a result of treatment with microtubule-depolymerizing drugs. A. The rearward traction forces exerted by the cells' actomyosin networks are counterbalanced by the tendency of the microtubules to elongate. Reduction in the number of microtubules would therefore result in a net increase in the traction forces. B. Upper panel: microtubules exert an inhibitory control on the organization and/or strength of cells' actomyosin, but only during microtubule elongation. Non-elongating (1.e. stable or shrinking) microtubules would not be inhibitory. Therefore, microtubule poisons would promote actin microfilament organization and contractility; Lower panel: a change in microtubule dynamics alters the ability of MAPs to remain bound to the microtubules. Release of MAPs stimulates cell contractility and/or promotes the formation of stress fibers.

and others (Fulton \& Isaacs, 1986; Ingber \& Jamieson, 1985; Buxbaum \& Heidemann, 1988), and it is supported by the results of Solomon \& Magendantz (1981) and Joshi et al. (1985), who observed that the retraction of nerve fibers is promoted by microtubule poisons; it is also supported by the observations of Letourneau et al. (1987), who demonstrated that a combination of taxol and cytochalasin B will cause neurites to extend forward. Recently, measurements of these pushing or compression forces have been made (Dennerll et al. 1988), and thermodynamic models developed to show how microtubule assembly might be regulated by changes in these compressive forces (Hill \& Kirschner, 1982; Buxbaum \& Heidemann, 1988).

Although this is an attractive hypothesis, there are 
certain aspects of the observations reported here that seem surprising or difficult to explain by a weakening of microtubule pushing forces. For example, in the taxoltreated cells, the microtubules were short and were clustered together near the center of the cell, and therefore did not span between the sites where contractile forces were being exerted on the substratum. Yet, as was described, the destruction of these short, central microtubules (by the removal of the taxol and addition of nocodazole) did result in the same increase in net contractile forces (Fig. 4). Thus, whatever pushing forces the microtubules had been exerting could not have been applied directly to the cell-substratum adhesions.

But this result is not inconsistent with some interpretations of tensegrity; for example, the model proposed by Heidemann, Buxbaum and colleagues to explain neurite shape and growth (Buxbaum \& Heidemann, 1988; Joshi et al. 1985; Dennerll et al. 1988). In their 'force counterbalance' model, the actin and the microtubules are linked laterally all along their length, wherever they overlap. Thus, even when the overlaps were confined to the central parts of the cell, the microtubules could still be counterbalancing a substantial part of the actin microfilaments' contractility.

There is another aspect of these observations that seems inconsistent with the counterbalance or tensegrity type of explanation. This is the observation that microtubule poisons promote the reorganization of actin stress fibers in cells that have had their stress fibers disrupted either by a tumor promoter or by drugs that elevate cytoplasmic cyclic AMP levels. However, the possibility should be considered that this reorganization of stress fibers is actually the effect, rather than the cause, of the increased tensile stress within the cell. In that case, the removal of microtubule struts could increase tension, and cause the actin to become bundled into stress fibers.

If tensegrity is responsible for these phenomena, then these results indicate that the compressive loads borne by the microtubules must be very large. For example, if a fibroblast were to double its contractility in response to microtubule-inhibiting drugs, its microtubules would have had to have been pushing with a force equal in strength to the net pulling forces that the cell had been exerting on the substratum prior to treatment with the drug.

A fourth class of possible explanations, that microtubules somehow modulate and exert an inhibitory control over actin organization, seems most consistent with our observations. The basic idea is that microtubules would somehow inhibit or weaken the organization and contractility of the actin, not just counterbalance its contraction, so that disruption of the microtubules would release the actin from this inhibition. This would allow the cells to contract more strongly and would even compensate for the disruption of stress fibers by agents such as tumor promoters and cyclic AMP stimulators.

Although such an inhibitory or modulating effect of microtubules on cytoplasmic actin does not seem to have been suggested previously, some of the recent discoveries about microtubule dynamics do suggest possible molecular mechanisms for the effects described here. In particu- lar, the in vitro observations of Mitchison \& Kirschner (1984) have revealed a 'dynamic instability' in which microtubules can elongate at relatively steady rates, but then depolymerize abruptly and rapidly. Dynamic instability of individual microtubules has also been observed to occur in living cells (Sammak \& Borisy, 1988; Schultze \& Kirschner, 1988; Cassimeris et al. 1988). If we suggest that contractility is controlled not so much by the simple presence of the microtubules, but rather by their dynamic state, then this would help to explain why such low concentrations of the drugs are able to stimulate fibroblast contraction. In this type of model, shown diagrammatically in Fig. 8B, contractility would be inhibited when microtubules are elongating, but not when they are either shrinking or stable. In addition, local dynamic depolymerization of microtubules in a particular part of the cell could serve as a means for stimulating increased nearby actin organization and contractility. This could explain how microtubules influence the spatial distributions of actin organization and function in cells (Vasiliev et al. 1970), and the role of dynamic instability in accomplishing this function.

How might microtubule instability serve to stimulate actin organization and contractility? The answer may involve specific microtubule-associated proteins (MAPs), as shown in the lower half of Fig. $8 \mathrm{~B}$. In vitro studies have shown that some MAPs can promote microtubule polymerization (Murphy \& Borisy, 1975), bind to intermediate filaments (Bloom \& Vallee, 1983), and cross-link actin filaments (Sattilaro et al. 1981; Griffith \& Pollard, 1982; Selden \& Pollard, 1983). Some in vivo evidence also suggests that certain MAPs interact with actin filaments (Hill et al. 1981; Vallee et al. 1984; Asai et al. 1985). If the release of MAPs from the microtubules were promoted by the microtubule poisons (even at low concentrations), and if these released MAPs were then to stimulate the contractility of actin and its organization into stress fibers, then the observed phenomena would result. During the revision of this manuscript, Okuhara et al. (1989) published the observation that the MAP kinesin does, in fact, associate with actin stress fibers following experimental disruption of microtubules.

The author acknowledges the support, guidance and encouragement of A. K. Harris throughout all aspects of this work. Thanks also to Dr R. E. Buxbaum and Dr S. Heidemann for their suggestions and criticisms, and to C. Bond, S. Gewalt, J. Dmytryk and P. Greenwell for helpful discussions. This research was funded by a grant from NIH (GM24251) to A.K.H.

\section{References}

Asai, D J., Thompson, W. C., Wilson, L., Dresden, C. F., Schulman, H. \& Purich, D. L. (1985). Microtubule-associated proteins (MAPs): A monoclonal antibody to MAP 1 decorates microtubules in vitro but stains stress fibers and not microtubules in vivo. Proc, natn. Acad. Sci. U.S.A. 82, 1434-1438.

Bershadsky, A. D. \& VAsiliev, J. M. (1988). Cytoskeleton. Plenum Press, New York.

Bloom, G. S. \& Vallee, R. B. (1983). Association of microtubuleassocrated protein 2 (MAP 2) with microtubules and intermediate filaments in cultured brain cells. F. Cell Biol. 96, 1523-1531. 
Buxbaum, R. E. \& Heidemann, S. R. (1988). A thermodynamic model for force integration and microtubule assembly during axonal elongation. 7 . theor. Biol. 134, 379-390.

Cassimeris, L., Pryer, N. K. \& Salmon, E. D. (1988). Real-time observations of microtubule dynamic instability in living cells. 7. Cell Biol. 107, 2223-2231.

Danowski, B. A. \& HaRRIS, A. (1988). Changes in fibroblast contractility, morphology and adhesion in response to a phorbol ester tumor promoter. Expl Cell Res. 177, 47-59.

De Brabander, M., Aerts, F., Van de Veire, R. \& Borgers, M. (1975). Evidence against interconversion of microtubules and filaments. Nature, Lond. 253, 119-120.

De Brabander, M., Geuens, G., Nuydens, R., Willebrords, R. \& DE MEY, J. (1981). Taxol induces the assembly of free microtubules in living cells and blocks the organizing capacity of the centrosomes and kinetochores. Proc. natn. Acad. Sci. US.A $78,5608-5612$

Dennerll, T. J., Joshi, H. C., Steel, V. L., Buxbaum, R. E. \& HeidemanN, S. R. (1988). Tension and compression in the cytoskeleton of PC-12 neurites. II. Quantitative measurements. $\mathcal{F}$. Cell Biol. 107, 665-674.

Dugina, V. B., Svttkina, T. M., Vasiliev, J. M. \& Gelfand, I. M. (1987). Special type of morphological reorganization induced by phorbol ester: Reversible partition of cell into motile and stable domains. Proc. natn. Acad. Sci. U.S.A. 84, 4122-4125.

Dustin, P. (1984). Microtubules, 2nd edn, Springer-Verlag, Berlin.

Edelman, G. M., Yahara, I. \& Wang, J. L. (1973). Receptor mobility and receptor-cytoplasmıc interactions in lymphocytes. Proc. natn. Acad. Sci. U.S.A. 70, 1442-1446.

Fulton, A. B. \& IsaCCS, W. B. (1986). Possible tensegrity models for the cytoskeleton. 7. Cell Biol. 103, 409a.

Gall, M. H. \& Boone, C. W. (1971). Effect of colcemid on fibroblast motılity. Expl Cell Res. 65, 221-227.

Griffith, L. M. \& Pollard, T. D. (1982). The interaction of actin filaments with microtubules and microtubule-associated proteins. 7. biol. Chem. 257, 9143-9151.

HARRIS, A. K. (1986). Cell traction in relationship to morphogenesis and malignancy, In Developmental Brology, vol. 3 (ed. Steinberg, M. S.), Plenum Publishing Corp., New York.

Harris, A. K., Stopak, D. \& WiLd, P. (1981). Fibroblast traction as a mechanism for collagen morphogenesis. Nature, Lond. 290 , $249-251$.

Harris, A. K., WiLd, P. \& Stopak, D. (1980). Silicone rubber substrata: A new wrinkle in the study of cell locomotion. Science 208, 177-179.

Hill, A.-M., Maunoury, R. \& Pantaloni, D. (1981). Cellular distribution of the microtubule-associated proteins HMW $(350 \mathrm{~K}$, $300 \mathrm{~K}$ ) by indirect immunofluorescence. Biol. Cell 41, 43-63.

HILL, T. C. \& KirSCHNER, M. W. (1982). Bioenergetics and kinetics of microtubule and actin filament assembly-disassembly. Int. Rev. Cytol. 78, 1-125.

IngBer, D. E. \& JAMieson, J. D. (1985). Cells as tensegrity structures: architectural regulation of histodifferentiation by physical forces transduced over basement membrane. In Gene Expression During Nonnal and Malgnant Differentiation, pp. 13-32, (Anderson, L. C., Gahnberg, C. G. \& Ekblom, P., eds) Academic Press, New York.

Joshi, H. C., Chu, D., Buxbaum, R. E. \& HeidemanN, S. R. (1985). Tension and compression in the cytoskeleton of PC 12 neurites. J. Cell Biol. 101, 697-705

Lamb, N. J. C., Fernandez, A., Conti, M. A., Adelstein, R., Glass, D. B., Welch, W. J. \& Feramisco, J. R. (1988). Regulation of actın microfilament integrity in living nonmuscle cells by the cAMP-dependent protein kinase and the myosin light chain kinase. J. Cell Biol. 106, 1955-1971.

Letourneau, P. C., Shattuck, T. A. \& Ressler, A. H. (1987).

"Pull" and "push" in neurite elongation: Observations on the effects of different concentrations of cytochalasin B and taxol. Cell Motil. Cutoskel. 8, 193-209.

Lyass, L. A., Bershadsky, A. D., Vasiliev, J. M. \& Gelfand, I M. (1988). Microtubule-dependent effect of phorbol ester on the contractility of cytoskeleton of cultured fibroblast. Proc, natn. Acad. Sci. U.S.A 85, 9538-9541.

Mrtchison, T. \& KirSCHNER, M. (1984). Dynamic instability of microtubule growth. Nature, Lond. 312, 237-242.

Murphy, D. B. \& Borisy, G. G. (1975). Association of highmolecular-weight proteins with microtubules, and their role in microtubule assembly in vitro. Proc. natn. Acad. Sci. U.S.A. 72 2696-2700.

Okuhara, K., Murofushi, H. \& Sakal, H. (1989). Binding of kinesin to stress fibers in fibroblasts under conditions of microtubule depolymerization. Cell Motil. Cytoskel. 12, 71-77.

Pollard, T. D., Fujiwara, K., Niederman, R. \& MaupinSzamier, P. (1976). In Cell Motility (Goldman, R., Pollard, T. D. \& Rosenbaum, J., eds), pp. 689-724. Cold Spring Harbor Laboratory Press, New York.

Poste, G., Papahadjopoulos, D., Jacobson, K. \& Vail, W. J (1975). Effects of local anesthetics on membrane properties. II. Enhancement of the susceptibility of mammalian cells to agglutination by plant lectins. Biochim. biophys. Acta 394 $520-539$.

RIfkiN, D. B., Crowe, R. M. \& Pollock, R. (1979). Tumor promoters induce changes in the chick embryo fibroblast cytoskeleton. Cell 18, 361-368.

Sammak, P. J. \& Borusy, G. G. (1988). Direct observation of microtubule dynamics in living cells. Nature, Lond. 332, 724-726

Sattilaro, R. F., Dentler, W. L. \& LeCluyse, E. L. (1981) Microtubule-assocrated proteins (MAPS) and the organization of actin filaments in vitro. 7 . Cell Biol. 90, 467-473.

Schiff, P. B. \& Horwitz, S. B. (1980). Taxol stabilizes microtubules in mouse fibroblast cells. Proc, natn. Acad. Sci. U.S.A. 77, 1561-1565.

Schliwa, M., Nakamura, T., Porter, K. R. \& Euteneuer, U. (1984). A tumor promoter induces rapid and coordinated reorganization of actin and vinculın in cultured cells. $\mathcal{F}$. Cell Biol. 99, 1045-1059.

SCHUltze, E. \& Kirschner, M. (1988). New features of microtubule behaviour observed in vivo. Nature, Lond. 334, 356-359.

Seamon, K. B., Padgett, H. W. \& Daly, J. W. (1981). Forskolın: Unique diterpene activator of adenylate cyclase in membranes and in intact cells. Proc. natn. Acad. Sci. U.S.A. 78, 3363-3367.

Selden, S. C. \& Pollard, T. D. (1983). Phosphorylation of microtubule-associated proteins regulates their interaction with actin filaments. 7. biol. Chem. 258, 7064-7071.

Solomon, F. \& Magendantz, M. (1981). Cytochalasin separates microtubule disassembly from loss of asymmetric morphology. $\mathcal{J}$. Cell Biol. 89, 157-161.

Starger, J. M., Brown, W. E., Goldman, A. E. \& Goldman, R. D. (1978). Biochemical and immunological analysis of rapidly purified 10-nm filaments from baby hamster kidney (BHK-21) cells. J. Cell Biol. 78, 93-109.

Stopak, D. \& Harris, A. K. (1982). Connective tissue morphogenesis by fibroblast traction. I. Tissue culture observations. Devl Biol. 90, 383-398.

Tomasek, J. J. \& HAY, E. D. (1984). Analygis of the role of microfilaments and microtubules in acquisition of bipolanty and elongation of fibroblasts in hydrated collagen gels. J. Cell Biol. 99 536-549.

Trinkaus, J. P. (1984). Cells into Organs. Prentice-Hall Inc., New Jersey.

Vallee, R. B., Bloom, G. S. \& Luca, F. C. (1984). Differential cellular and subcellular distribution of microtubule-associated proteins. In Molecular Biology of the Cytoskeleton, pp. 111-130 (G. G. Borisy, D. W. Cleveland \& D. B. Murphy, eds). Cold Spring Harbor Laboratory Press, New York.

Vasiliev, J. M., Gelfand, I. M., Domnina, L. V., Ivanova, O Y., Kомm, S. G. \& Olshevskaja, L. V. (1970) Effect of colcemid on the locomotory behaviour of fibroblasts. F. Embryol. exp. Morph 24, 625-640.

(Received December 1988 - Accepted, in revised form, March 1989) 